\title{
Influence of agricultural environment on the plant mite community in forest fragments
}

\author{
Demite, PR. ${ }^{a, b *}$, Feres, RJF. $^{c}$ and Lofego, $A C^{c}$ \\ aPrograma de Pós-Graduação em Biologia Animal, Universidade Estadual Paulista "Júlio de Mesquita Filho" - UNESP, \\ Rua Cristovão Colombo, 2265, CEP 15054-000, São José do Rio Preto, SP, Brazil \\ 'Instituto Federal Goiano, Campus Urutaí, Rodovia Geraldo Silva Nascimento, Km 2,5, \\ CEP 75790-000, Urutaí, GO, Brazil \\ 'Departamento de Zoologia e Botânica, Universidade Estadual Paulista "Júlio de Mesquita Filho" - UNESP, \\ Rua Cristovão Colombo, 2265, CEP 15054-000, São José do Rio Preto, SP, Brazil \\ *e-mail: peterson_demite@yahoo.com.br
}

Received: August 13, 2013 - Accepted: February 27, 2014 - Distributed: May 31, 2015

(With 4 Figures)

\begin{abstract}
The mite community has been surveyed in Seasonal Semideciduous Forest with three types of surrounding agricultural environments to test the hypothesis that abundance and richness of mites in forest fragments are influenced by the type of agricultural environment. The survey has been carried out in six fragments, divided into sets of two fragments, each one neighboring one sort of agricultural environment: sugarcane crop (FS), orange crop (FO) and pasture (FP). In each fragment, ten individuals of Actinostemon communis (Euphorbiaceae) were selected, five at the edge and five within each fragment. Iphiseiodes zuluagai, often registered in orange crops, was more abundant in the fragments neighboring such crop, as well as some species of Tarsonemidae. In this study, the Phytoseiidae were more abundant in the fragments neighboring pasture, while sugarcane crops probably favored occurrence of phytophagous mites in the neighboring fragments. Tetranychidae were less abundant in FO, which can be explained by periodical use of pesticides in the orange crops. Forest fragments are important for colonies of predators in the neighboring crops, mainly for annual crops such as sugarcane, where the close perennial environment is very important for colonization of the crop. Maintenance of those areas, besides favoring preservation of wild species of mite, is very important to increase diversity of the neighboring agricultural ecosystems.
\end{abstract}

Keywords: agroecosystems, native areas, edge effect, forest fragments.

\section{Influência do ambiente agrícola vizinho na comunidade de ácaros plantícolas em fragmentos florestais}

\section{Resumo}

Foi estudada a comunidade de ácaros em fragmentos de mata estacional semidecidual com três tipos de ambientes agrícolas circunvizinhos para testar a hipótese de que a abundância e a riqueza de ácaros em fragmentos florestais são influenciadas pelo tipo de ambiente agrícola. O estudo foi conduzido em seis fragmentos, divididos em três conjuntos de dois fragmentos, sendo cada conjunto vizinho de um determinado tipo de ambiente agrícola: canavial (FS), laranjal (FO) e pastagem (FP). Em cada fragmento foram selecionados e marcados dez indivíduos de Actinostemon communis (Euphorbiaceae), cinco na borda e cinco no interior do fragmento. Iphiseiodes zuluagai, registrado frequentemente em laranjais, foi mais abundante nos fragmentos vizinhos a essa cultura, bem como algumas espécies de Tarsonemidae. Neste estudo os fitoseídeos foram mais abundantes nos fragmentos vizinhos de áreas de pastagens, enquanto os cultivos de cana-de-açúcar provavelmente favoreceram a ocorrência de fitófagos nos fragmentos adjacentes. Os tetraniquídeos foram menos abundantes em FO, o que pode ser explicado pela aplicação periódica de pesticidas nos laranjais. Fragmentos florestais são importantes para a colonização de predadores nas culturas vizinhas, principalmente em culturas anuais, como a cana-de-açúcar, nas quais o ambiente perene próximo é muito importante para a colonização do cultivo. A conservação dessas áreas, além de favorecer a manutenção de espécies silvestres de ácaros é de grande importância para o aumento da diversidade nos agroecossistemas vizinhos.

Palavras-chave: agroecossistemas, áreas nativas, efeito de borda, remanescentes florestais. 


\section{Introduction}

Fragmentation is the process by which continuous areas are subdivided into smaller size areas due to destruction of the habitat (Lovejoy et al., 1986), mainly due to intense use of the land (Burgess and Sharpe, 1981). In areas with anthropic changes, use of agricultural landscape frequently creates mosaics of clearly contrasting types of habitats (Tscharntke et al., 2002). Fragmentation and loss of habitat are closely related processes (Laurance and Bierregaard Junior, 1997), considered to be the worst threatens to the planet's biodiversity (Saunders et al., 1991; Tscharntke, 1992; Wilcove et al., 1986; Tabarelli and Gascon, 2005). With the fragmentation process, the remaining areas are surrounded by different types of vegetation and/or use of the soil, like pasture, crops and secondary vegetation, and a sudden border is created between the forest and the surrounding environment (Saunders et al., 1991), exposing the organisms of the remnants to the conditions of a different neighboring ecosystem (Murcia, 1995).

In Brazil, some surveys have already been developed to analyse influence of the neighboring vegetation on occurrence of mite in cultivation of rubber-tree (Demite and Feres, 2005, 2008), orange (Albuquerque, 2006) and coffee (Silva et al., 2010; Berton 2009). Demite and Feres (2007) also studied the relevance of native areas as reservoirs for Hirsutella thompsonii, an entomopathogenic fungus registered attacking the phytophagous mites more abundant in cultivation of rubber-tree crop in Mato Grosso State. However, no survey has been carried out to analyse influence of agricultural environments on mite community of neighboring forest remnants.

To test the hypothesis that the agricultural environment influences abundance and occurrence of mites in neighboring forest fragments, the plant Actinostemonis communis (Euphorbiaceae) has been selected, one of the most commonly occurring native plants species in the region wherein the survey has been carried out, as a model to assess the mite community in fragments with three types of surrounding agricultural environments.

\section{Material and Methods}

\subsection{Surveyed areas}

The survey was carried out in six fragments neighboring three types of agricultural environments typical of the Northwestern region of São Paulo State (Table 1):
(1) fragments neighboring sugarcane crops (FS), (2) orange crops (FO) and (3) pasture (FP). The distance between forest fragments and neighboring agricultural environments was about three meters. For each sampled fragments, the shape index was calculated ("Shape Index" - SI, sensu Patton (1975), modified by Laurance and Yensen, 1991), which value is directly proportional to the fragments edge area in relation to its total size. Higher index correspond to forest fragments with more irregular shapes, so a higher edge area. The minimum value $(\mathrm{SI}=1)$ is a fragment of circular shape.

\subsection{Sampling}

In each fragment, ten individual of Actinostemon communis (Müll Arg.) Pax. (Euphorbiaceae) were selected and marked, being, five at the edge and five within each fragment. The samplings were performed once every three months, from July 2007 to April 2009. Qualitatives samplings was also performed in the neighboring agricultural environment of each surveyed fragment.

During the collections, leaves around the plants were sampled and stored in paper bags inside polyethylene bags, kept on isothermal polystyrene boxes with ice. For each individual plant, a number of leaves in which the sum of the lengths was $250 \mathrm{~cm}$ (in average 39 leaves/individual) was evaluated. In the laboratory, the material was stored at $10^{\circ} \mathrm{C}$ for 72 up to hours. Collected material was examined under stereomicroscope $(40 \times)$ and the mites found were mounted in Hoyer's medium. Oribatid mites were not evaluated in this study. Examination to identify the specimens was performed with optical microscope with phases contrast.

\subsection{Statistical analyses}

Repeated measurement ANCOVA has been used to compare population density (number of mites $/ \mathrm{dm}^{2}$ ) and richness (number of species/dm²) of the mites community and the most representative families (Phytoseiidae, Tarsonemidae and Tetranychidae), among the fragments surrounded by the different types of agricultural environments (sugarcane crop, orange crop and pasture). For such analysis, the fragments area and the shape index of the fragments were used as co-variables. To distinguish the averages, the Fisher's $a$ posteriori test (LSD) was used. The data not presenting homogeneity of variance was changed into log (Zar, 1999). Only adults of each species were considered, as for almost all it is not possible to identify them, in a reliable manner, using immature shapes.

Table 1. Location, area and shape indexes of the fragments neighboring the three types of agricultural environments analyzed.

\begin{tabular}{cccrc}
\hline Location & Coordinates & Agricultural Enrivonment & Area & SI* $^{*}$ \\
\hline Barretos & $20^{\circ} 38^{\prime} \mathrm{S}, 48^{\circ} 45^{\prime} \mathrm{W}$ & Sugarcane & 95.12 & 1.43 \\
S.J. de Iracema & $20^{\circ} 28^{\prime} \mathrm{S}, 50^{\circ} 17^{\prime} \mathrm{W}$ & Sugarcane & $1,656.20$ & 2.87 \\
Matão & $21^{\circ} 37^{\prime} \mathrm{S}, 48^{\circ} 32^{\prime} \mathrm{W}$ & Orange & $2,189.58$ & 2.36 \\
Taquaritinga & $21^{\circ} 24^{\prime} \mathrm{S}, 48^{\circ} 41^{\prime} \mathrm{W}$ & Orange & 55.53 & 1.28 \\
Turmalina & $20^{\circ} 00^{\prime} \mathrm{S}, 50^{\circ} 26^{\prime} \mathrm{W}$ & Pasture & 107.91 & 1.39 \\
União Paulista & $20^{\circ} 55^{\prime} \mathrm{S}, 49^{\circ} 55^{\prime} \mathrm{W}$ & Pasture & 230.36 & 1.34 \\
\hline
\end{tabular}

*Shape Index. 


\section{Results}

Seventy-four species of mites were registered, belonging to 19 families (Table 2). The Phytoseiidae, Tarsonemidae and Tetranychidae families sheltered $54 \%$ of all the species registered, and $69 \%$ of all the collected adult mites.
The higher population density of mites was registered in FS and FP, in comparison to FO (Figure 1a). As for richness values, they were very close between FS and FP, and lower in FO (Figure 1b).

In FP, the Phytoseiidae mites population density was higher than FS and FO (Figure 2a). As for richness, there

Table 2. Abundance of the mite species registered in the fragments neighboring the three types of agricultural environments.

\begin{tabular}{|c|c|c|c|c|c|}
\hline \multirow[b]{2}{*}{ Family } & \multirow[b]{2}{*}{ Species } & \multicolumn{3}{|c|}{$\begin{array}{c}\text { Fragment/Agricultural } \\
\text { Environment }\end{array}$} & \multirow[t]{2}{*}{ Total } \\
\hline & & FS & FO & FP & \\
\hline Acaridae & Sancassania sp. & & 2 & 1 & 3 \\
\hline Anystidae & Erythracarus sp. & & 2 & & 2 \\
\hline \multirow[t]{4}{*}{ Ascidae } & Asca sp.1 & 1 & & & 1 \\
\hline & Asca sp.2 & 5 & 1 & 23 & 29 \\
\hline & Asca sp.3 & 4 & 4 & 18 & 26 \\
\hline & Asca sp.4 & 2 & & 3 & 5 \\
\hline \multirow[t]{4}{*}{ Cheyletidae } & Cheletogenes cf. ornatus & & 1 & & 1 \\
\hline & Cheletomimus (C.) cf. duosetosus & 13 & & 8 & 21 \\
\hline & Cheletomimus (H.) cf. wellsii & 2 & 4 & & 6 \\
\hline & Chiapacheyllus cf. edentatus & 2 & & 1 & 3 \\
\hline \multirow[t]{3}{*}{ Cunaxidae } & Cunaxa sp. & & 1 & & 1 \\
\hline & Cunaxatricha tarsospinosa & 2 & 1 & & 3 \\
\hline & Scutopalus sp. & & & 1 & 1 \\
\hline Eriophyidae & Anthocoptini sp. & & & 51 & 51 \\
\hline Eupodidae & Eupodes sp. & & 1 & & 1 \\
\hline \multirow[t]{3}{*}{ Iolinidae } & Homeopronematus sp. & 157 & 4 & 66 & 227 \\
\hline & Parapronematus sp. & 21 & 13 & 32 & 66 \\
\hline & Pronematus sp. & 32 & 5 & 11 & 48 \\
\hline Laelapidae & Pseudoparasitus sp. & & 1 & & 1 \\
\hline \multirow[t]{18}{*}{ Phytoseiidae } & Amblydromalus manihoti & & 1 & & 1 \\
\hline & Amblyseius acalyphus & 1 & & & 1 \\
\hline & Amblyseius aerialis & 46 & & 27 & 73 \\
\hline & Amblyseius biotafapesp & & & 95 & 95 \\
\hline & Amblyseius chiapensis & & & 1 & 1 \\
\hline & Amblyseius compositus & 3 & 1 & & 4 \\
\hline & Amblyseius herbicolus & 2 & 16 & & 18 \\
\hline & Amblyseius neochiapensis & 1 & & & 1 \\
\hline & Amblyseius paulofariensis & 42 & 18 & 24 & 84 \\
\hline & Euseius citrifolius & 82 & 9 & 21 & 112 \\
\hline & Euseius concordis & 27 & 118 & 220 & 365 \\
\hline & Euseius sibelius & 1 & & & 1 \\
\hline & Iphiseiodes zuluagai & 1 & 32 & 6 & 39 \\
\hline & Neoseiulus tunus & 46 & 31 & 87 & 164 \\
\hline & Proprioseiopsis cannaensis & 1 & & 1 & 2 \\
\hline & Proprioseiopsis dominigos & & 1 & 1 & 2 \\
\hline & Transeius bellottii & 1 & & 1 & 2 \\
\hline & Typhlodromalus aripo & 1 & & 1 & 2 \\
\hline Raphignathidae & Raphignathus sp. & & & 1 & 1 \\
\hline \multirow[t]{2}{*}{ Stigmaeidae } & Agistemus sp. & 12 & & 12 & 24 \\
\hline & Zetzellia agistzellia & & 1 & & 1 \\
\hline Tarsonemidae & Daidalotarsonemus folisetae & & & 1 & 1 \\
\hline
\end{tabular}

\footnotetext{
(FS) Fragments neighboring sugarcane crops; (FO) Fragments neighboring orange crops; (FP) Fragments neighboring pasture.
} 
Table 2. Continued...

\begin{tabular}{|c|c|c|c|c|c|}
\hline \multirow[b]{2}{*}{ Family } & \multirow[b]{2}{*}{ Species } & \multicolumn{3}{|c|}{$\begin{array}{c}\text { Fragment/Agricultural } \\
\text { Environment }\end{array}$} & \multirow[t]{2}{*}{ Total } \\
\hline & & FS & FO & FP & \\
\hline & Daidalotarsonemus tessellatus & & 1 & 6 & 7 \\
\hline & Floridotarsonemus sp.1 & 1 & & & 1 \\
\hline & Floridotarsonemus sp. 2 & 1 & & & 1 \\
\hline & Fungitarsonemus pulvirosus & 59 & 31 & 38 & 128 \\
\hline & Fungitarsonemus sp.1 & 25 & 12 & 12 & 49 \\
\hline & Fungitarsonemus sp.2 & 17 & 44 & 6 & 67 \\
\hline & Fungitarsonemus sp.3 & & 1 & 1 & 2 \\
\hline & Metatarsonemus megasolenidii & 1 & 43 & 18 & 62 \\
\hline & Metatarsonemus sp.1 & & 1 & & 1 \\
\hline & Tarsonemus confusus & 1 & 4 & 2 & 7 \\
\hline & Tarsonemus sp.1 & & 3 & 1 & 4 \\
\hline & Tarsonemus sp.2 & & 18 & & 18 \\
\hline & Tarsonemus sp. 3 & & 1 & & 1 \\
\hline & Xenotarsonemus brachytegula & & 1 & 25 & 26 \\
\hline & Xenotarsonemus gordoni & & 2 & & 2 \\
\hline & Xenotarsonemus sp.1 & & 6 & 1 & 7 \\
\hline & Xenotarsonemus sp.2 & & 1 & & 1 \\
\hline Tenuipalpidae & Brevipalpus phoenicis & 1 & & 2 & 3 \\
\hline \multirow[t]{4}{*}{ Tetranychidae } & Aponychus sp. & & 1 & & 1 \\
\hline & Mononychellus sp. & & & 1 & 1 \\
\hline & Neotetranychus asper & & & 1 & 1 \\
\hline & Tetranychus riopretensis & 604 & 10 & 221 & 835 \\
\hline \multirow[t]{2}{*}{ Triophtydeidae } & Metatriophtydeus sp. & 11 & 2 & 13 & 26 \\
\hline & Pseudotriophtydeus sp. & & 1 & 5 & 6 \\
\hline \multirow[t]{5}{*}{ Tydeidae } & Lorryia formosa & 18 & 146 & 36 & 200 \\
\hline & Lorryia sp.1 & 6 & 55 & 10 & 71 \\
\hline & Lorryia sp.2 & 1 & & & 1 \\
\hline & Neolorryia sp. & & 3 & & 3 \\
\hline & Pretydeinae sp. & 1 & & & 1 \\
\hline \multirow[t]{3}{*}{ Winterschmidtiidae } & Czenspinskia sp. & 50 & 3 & 27 & 80 \\
\hline & Oulenzia sp.1 & 14 & & 5 & 19 \\
\hline & Oulenzia sp.2 & 6 & 27 & 2 & 35 \\
\hline Incertae sedis & Africoseius sp. & & 1 & 1 & 2 \\
\hline Abundance & & 1.325 & 686 & 1.148 & 3.159 \\
\hline Richness & & 43 & 48 & 48 & 74 \\
\hline
\end{tabular}

(FS) Fragments neighboring sugarcane crops; (FO) Fragments neighboring orange crops; (FP) Fragments neighboring pasture.

has not been evidenced difference among the neighboring fragments to the three types of agricultural environment for the mites of that family (Figure 2b). For the Tarsonemidae, the neighboring agricultural environment did not affect abundance and richness in the fragments, although it was tends to be greater in FO (Figure 3). Tetranychidae were twice more abundant in FS than in FP, and more than ten times more abundant than in FO (Figure 4a); the number of species was not different between FS and FP, and it was smaller in FO (Figure 4b). Some species were more abundant in fragments neighboring a certain type of agricultural environment: Euseius concordis (Chant, 1959) and Neoseiulus tunus (De Leon, 1967), the more abundant
Phytoseiidae registered in the study were more common in the fragments neighboring pasture; Tetranychus riopretensis Feres and Flechtmann, 1996 (Tetranychidae) was more abundant in fragments neighboring to sugarcane crops and Iphiseiodes zuluagai Denmark \& Muma, 1972 (Phytoseiidae), Fungitarsonemus sp.2 (Tarsonemidae) and Metatarsonemus megasolenidii Lofego \& Ochoa, 2005 (Tarsonemidae) were more common in the fragments neighboring orange crops (Table 3).

Six species of Phytoseiidae and four of Tarsonemidae which were registered in the agricultural environments were also registered in the respective neighboring fragments (Table 4). Euseius concordis was registered in the three 

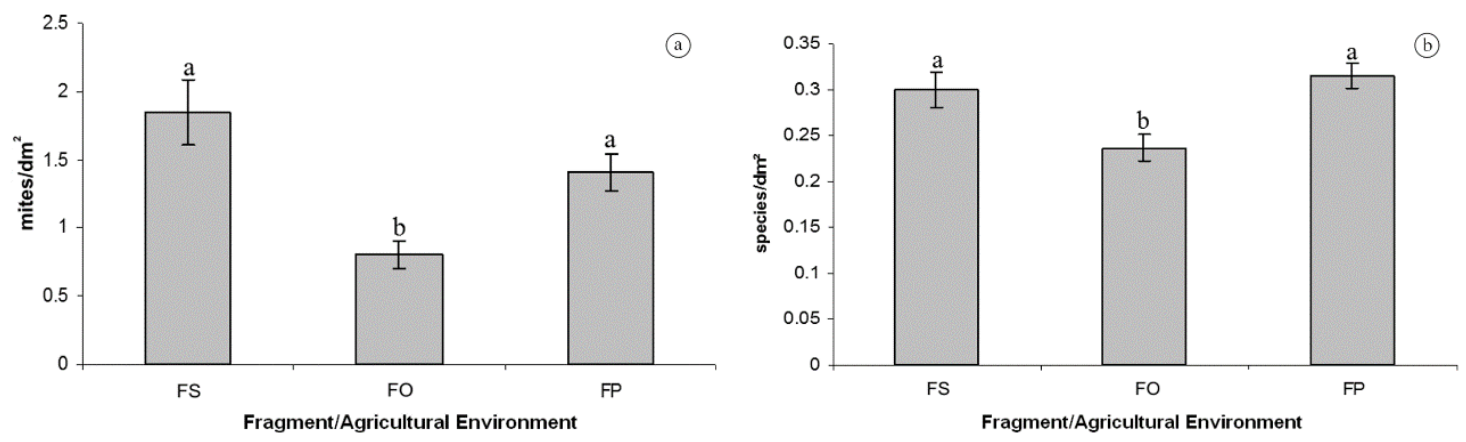

Figure 1. a. Mites density registered in A. communis in the fragments neighboring the three types of agricultural environments $\left(F_{2,57}=9.78 ; p<0.001\right)$. b. Richness of species registered in $A$. communis in the fragments neighboring the three types of agricultural environments $\left(F_{2,57}=3.96 ; p<0.05\right)$. Averages \pm Standard Deviation are informed. Different letters indicate significant statistic differences $(p<0.05)$. (FS) Fragments neighboring sugarcane crops; (FO) Fragments neighboring orange crops; (FP) Fragments neighboring pasture.
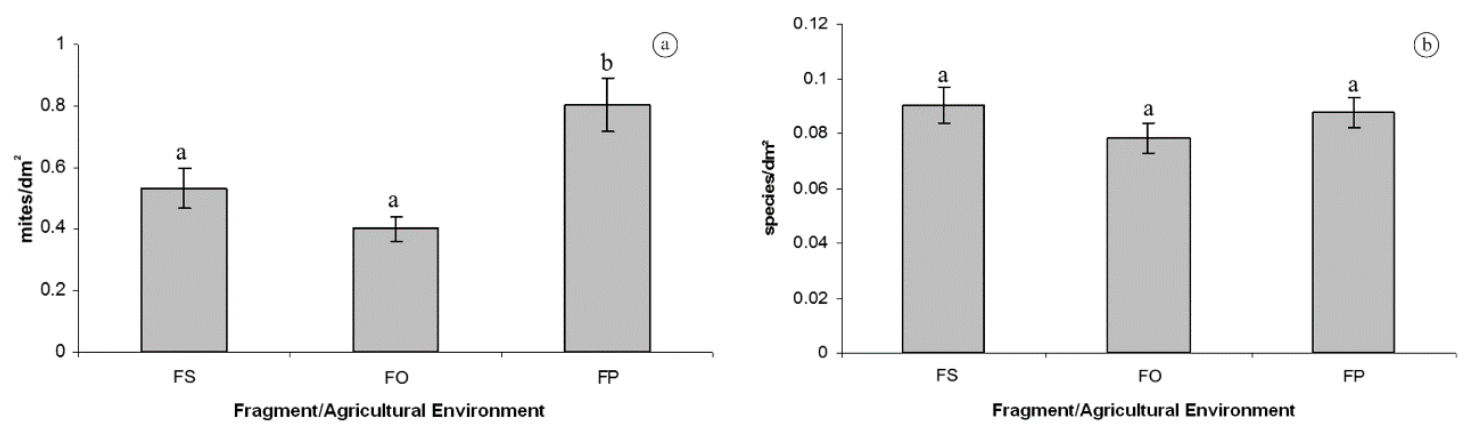

Figure 2. a. Density of Phytoseiidae registered in A. communis in the fragments neighboring the three types of agricultural environments $\left(F_{2.57}=9.78 ; p<0.001\right)$. b. Richness of Phytoseiidae species registered in $A$. communis in the fragments neighboring the three types of agricultural environments $\left(F_{2.57}=0.03 ; p<0.86\right)$. Averages \pm Standard Deviation are informed. Different letters between the columns indicate significant statistic differences $(p<0.05)$. (FS) Fragments neighboring sugarcane crops; (FO) Fragments neighboring orange crops; (FP) Fragments neighboring pasture.
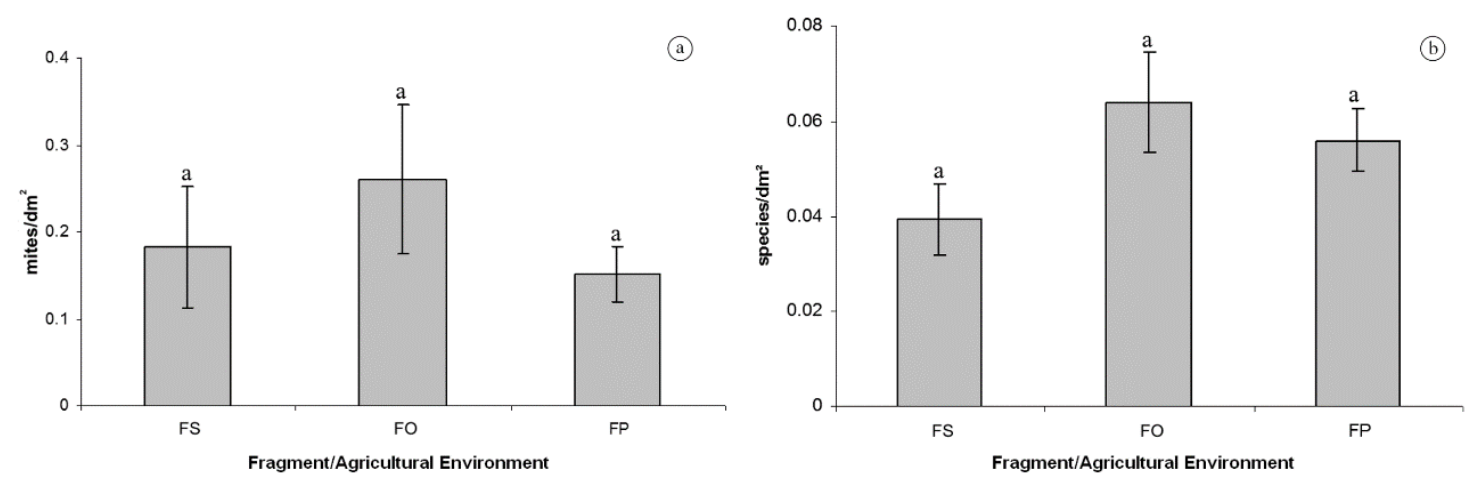

Figure 3. a. Density of Tarsonemidae registered in $A$. communis in the fragments neighboring the three types of agricultural environments $\left(F_{257}=1.99 ; p=0.14\right)$. b. Richness of Tarsonemidae species registered in $A$. communis in the fragments neighboring the three types of agricultural environments $\left(F_{2,57}=0.67 ; p=0.51\right)$. Averages \pm Standard Deviation are informed. Different letters between the columns indicate significant statistic differences $(p<0.05)$. (FS) Fragments neighboring sugarcane crops; (FO) Fragments neighboring orange crops; (FP) Fragments neighboring pasture.

agricultural environments and also in the neighboring fragments. However, some species of Phytoseiidae and Tarsonemidae which were registered in the fragments were not found in all the neighboring agricultural environments:
I. zuluagai was registered in the orange crops and in the pasture; Tarsonemus confusus Ewing, 1939 in the sugarcane and in the orange crops and Fungitarsonemus pulvirosus Attiah, 1970 and Fungitarsonemus sp. 2 in the 

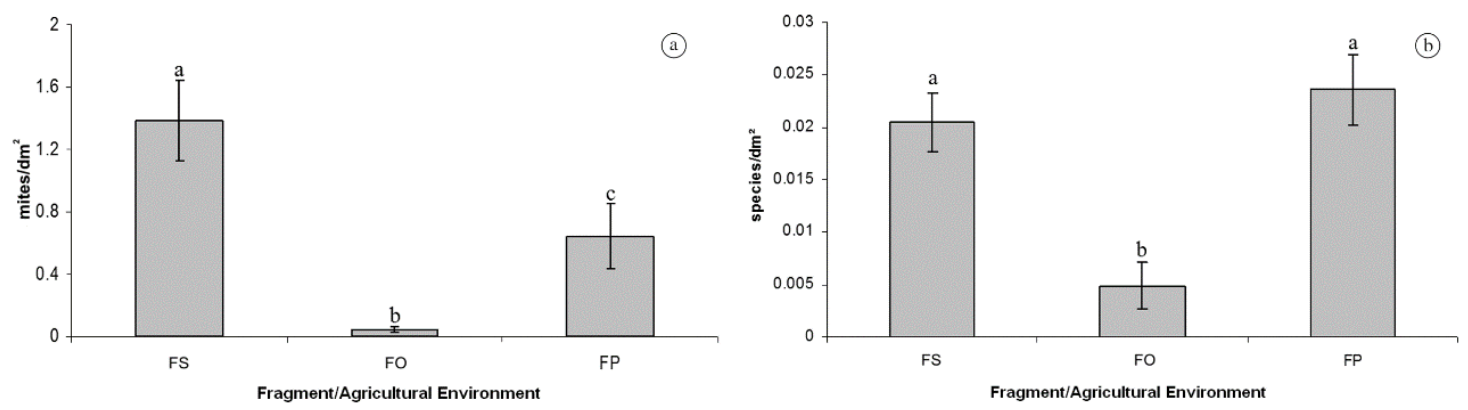

Figure 4. a. Density of Tetranychidae registered in A. communis in the fragments neighboring the three types of agricultural environments $\left(F_{2.57}=33.73 ; p<0.001\right)$. b. Richness of Tetranychidae registered in A. communis in the fragments neighboring the three types of agricultural environments $\left(F_{2,58}=17.59 ; p<0.001\right)$. Averages \pm Standard Deviation are informed. Different letters between the columns indicate significant statistic differences $(p<0.05)$. (FS) Fragments neighboring sugarcane crops; (FO) Fragments neighboring orange crops; (FP) Fragments neighboring pasture.

Table 3. Density of the most abundant species of the three families analyzed in the survey, in relation to the type of agricultural enrivonment neighboring the fragments. Averages \pm Standard Deviation are informed. Different letters between the columns indicate significant statistic differences $(p<0.05)$.

\begin{tabular}{ccccc}
\hline & & \multicolumn{2}{c}{ Fragments/Agricultural Environment } \\
\hline Family & Species & FS & FO & FP \\
\hline Phytoseiidae & Amblyseius aerialis & $0.06 \pm 0.02 \mathrm{a}$ & $0 \mathrm{c}$ & $0.02 \pm 0.01 \mathrm{~b}$ \\
& Amblyseius paulofariensis & $0.05 \pm 0.02$ & $0.02 \pm 0.01$ & $0.03 \pm 0.03$ \\
& Amblyseius biotafapesp & $0 \mathrm{~b}$ & $0 \mathrm{~b}$ & $0.0011 \pm 0.0005 \mathrm{a}$ \\
& Euseius citrifolius & $0.12 \pm 0.03 \mathrm{a}$ & $0.01 \pm 0.007 \mathrm{~b}$ & $0.03 \pm 0.01 \mathrm{~b}$ \\
& Euseius concordis & $0.03 \pm 0.0001 \mathrm{~b}$ & $0.14 \pm 0.02 \mathrm{~b}$ & $0.28 \pm 0.06 \mathrm{a}$ \\
Tarsonemidae & Iphiseiodes zuluagai & $0.001 \pm 0.001 \mathrm{~b}$ & $0.04 \pm 0.0001 \mathrm{a}$ & $0.006 \pm 0.003 \mathrm{~b}$ \\
& Neoseiulus tunus & $0.06 \pm 0.02 \mathrm{a} . \mathrm{b}$ & $0.04 \pm 0.01 \mathrm{~b}$ & $0.10 \pm 0.03 \mathrm{a}$ \\
& Fungitarsonemus pulvirosus & $0.09 \pm 0.03 \mathrm{a}$ & $0.03 \pm 0.02 \mathrm{~b}$ & $0.05 \pm 0.01 \mathrm{~b}$ \\
& Fungitarsonemus sp.1 & $0.04 \pm 0.01 \mathrm{a}$ & $0.01 \pm 0.005 \mathrm{~b}$ & $0.01 \pm 0.01 \mathrm{~b}$ \\
& Fungitarsonemus sp.2 & $0.006 \pm 0.004 \mathrm{~b}$ & $0.06 \pm 0.03 \mathrm{a}$ & $0.01 \pm 0.004 \mathrm{~b}$ \\
& Metatarsonemus megasolenidii & $0.02 \pm 0.008 \mathrm{~b}$ & $0.05 \pm 0.01 \mathrm{a}$ & $0.02 \pm 0.008 \mathrm{~b}$ \\
& Xenotarsonemus brachytegula & 0 & $0.001 \pm 0.001$ & $0.03 \pm 0.002$ \\
\hline
\end{tabular}

(FS) Fragments neighboring sugarcane crops; (FO) Fragments neighboring orange crops; (FP) Fragments neighboring pasture.

Table 4. Phytoseiidae and Tarsonemidae species, synchronically occurring in the fragments and agricultural environments.

Agricultural Environment

\begin{tabular}{|c|c|c|c|c|}
\hline Family & Species & Sugarcane & Orange & Pasture \\
\hline \multirow[t]{6}{*}{ Phytoseiidae } & Amblyseius acalyphus & $\mathrm{X}$ & & \\
\hline & Amblyseius chiapensis & & $\mathrm{X}$ & \\
\hline & Euseius citrifolius & & $\mathrm{X}$ & \\
\hline & Euseius concordis & $\mathrm{X}$ & $\mathrm{X}$ & $\mathrm{X}$ \\
\hline & Iphiseiodes zuluagai & & $\mathrm{X}$ & $\mathrm{X}$ \\
\hline & Proprioseiopsis dominigos & & & $\mathrm{X}$ \\
\hline \multirow[t]{4}{*}{ Tarsonemidae } & Fungitarsonemus pulvirosus & & $X$ & \\
\hline & Fungitarsonemus sp.2 & & $\mathrm{X}$ & \\
\hline & Tarsonemus confusus & $\mathrm{X}$ & $\mathrm{X}$ & \\
\hline & Tarsonemus sp.3 & & $\mathrm{X}$ & \\
\hline
\end{tabular}


orange crops. No species of Tetranychidae registered in the fragments was collected in the agricultural environments neighboring the forest fragments.

\section{Discussion}

Agricultural environments can affect occurrence of mites in the neighboring fragments. In a survey performed by Lofego et al. (2009), 20 Phytoseiidae species has been registered in the most common species of grass in São Paulo State. Among them, nine were also recorded in this study [Amblyseius acalyphus Denmark and Muma, 1973, A. chiapensis De Leon, 1961, A. neochiapensis Lofego, Moraes and McMurtry, 2000, E. citrifolius Denmark and Muma, 1970, E. concordis (most abundant in grass), E. sibelius (De Leon, 1962), I. zuluagai, Proprioseiopsis cannaensis Muma, 1962 and Typhlodromalus aripo De Leon, 1967]. Those authors discuss the roles of those plants as Phytoseiidae reservoirs with potential for use in biological control programs. In this study, the Phytoseiidae was more abundant in fragments neighboring pasture. On the other hand, sugarcane crops have probably contributed for occurrence of Tetranychidae in the neighboring fragments. However, when the neighboring agricultural environment was orange crop, abundance of Tetranychiidae in the fragments was quite smaller, probably due to the effects of pesticide use in the orange crops.

The surrounding agricultural environment is largely relevant for preserving the species that dwell in the forest remnants. According to Vandermeer and Perfecto (1997), management of such environment must be the key for preservation of the landscape level. Use of pesticides in the neighboring crops can have negative impact on the fragments. Perfecto and Vandermeer (2002) have found greater richness of ants in a fragment neighboring the area that has not received application of pesticides. Although many cases of Phytoseiidae resistance to pesticides are known (Hoy, 1990), species such as E. citrifolius and I. zuluagai are sensitive to some products used for pest control in orange crops (Sato et al., 1994, 1996). Use of non-selective pesticides can affect the beneficial organisms that might act upon control of phytophagous species, thus enabling occurrence of pests (Vidal and Kreiter, 1995). Therefore, strategies to reduce use of such products in the crop, or at least which avoid use in a portion of the crop close to the remnants should be taken into account in order to preserve the neighboring natural environment. Demite and Feres (2008) suggested that use of pesticides should be avoided in rubber-trees close to native areas, aiming to protect the fauna of predators which are found in there.

Another attitude that might impair preservation of wild species in the forest remnants is burn of straw in the sugarcane crop. Such practice aiming to facilitate harvest, has been frequently used in the studied region and it might impair the organisms that dwell in the neighboring natural environments, mainly in the edge. Improper management of crops, with unreasonable use of pesticides and fire can affect the neighboring fragments (Colli et al., 2003).

Besides favoring the mites' populations in the forest remnants, strategies taken aiming to preserve those environments can also favor the neighboring agricultural environment. Several essays have documented that native areas favor migration of natural enemies to agricultural ecosystems (Altieri et al., 2003; Tixier et al., 1998, 2000). Jung and Croft (2001) studied air dispersion of some species of Phytoseiidae which colonized vineyards from the neighboring natural vegetation, and abundance of Phytoseiidae and proximity of natural vegetation had direct relation with colonization of those predators in the vineyard (Tixier et al., 1998, 2000). Hence, forest remnants can serve as reservoirs of predator mites. In those environments, the predators have access to alternative food sources (like pollen and nectar), shelter, reproduction sites and alternative substrates during the periods when preys are scarce in the crops, where supposedly they must control the pests (Chiverton and Sotherton, 1991). Thus, predator mites can re-colonize the neighboring environment after use of non-selective pesticides in the crop or after a period of scarcity of preys in such environment.

Registration of some species collected in the fragments and in the three agricultural environments contributes for the hypothesis that such mites can travel across the two environments, even if accidentally. The close proximity of the forest fragments sampled in this study with the neighboring agricultural environments (few meters) may have facilitated the passage of predatory mites (Phytoseiidae mostly) between the two environments, both a the ambulatory and aerial dispersal. According to Bernstein (1983), Phytoseiulus persimilis Athias-Henriot, 1957 (Phytoseiidae) can go in one day almost $50 \mathrm{~m}$ straight line. The intensity and direction of wind, that it can not be measured in this study, also can influence the dispersal of mites (aerial dipersal) between environments. The phoresis can also be another dispersal mechanism, but this is still unclear. According to Altieri and Todd (1981) and Coombes and Sotherton (1986), predators can be taken from the woods to the crop and vice-versa, which has been reassured by several essays. In the case of phytophagous mites, the wind seems to be the main dispersal mechanism (e.g. Bergh and McCoy, 1997; Bergh, 2001; Alves et al., 2005).

Lofego et al. (2004) in a survey of Phytoseiidae mites carried out with native species of Myrtacea in fragments of Cerrado in São Paulo State, observed that several species of Phytoseiidae found in that biome are also commonly found in the most common crops of that State, such as orange crops and cultivations of rubber-tree, indicating possible migration of such mites across the environments. Demite and Feres $(2005,2008)$ reported occurrence of E. citrifolius, E. concordis and I. zuluagai in cultivations of rubber-trees, as well as in native areas close to the plantations. Silva et al. (2010) and Berton (2009) also verified occurrence of those three phytoseiids species in coffee crops neighboring forest fragments in the south of 
Minas Gerais State and neighboring a forest fragment in the city of Monte Alegre do Sul, São Paulo State, respectively. Albuquerque (2006) registered E. concordis and I. zuluagai in orange crops and in the neighboring vegetation, in the city of Jaguariúna, São Paulo State. No Tetranychidae registered in the fragments was sampled in the agricultural environments. Travelling of phytophagous mites across environments is not as common as travelling of predator mites probably due to those organisms' association to the host plants.

Forest fragments may have a very important role for predators' colonization in neighboring agricultural ecosystems, mainly in annual crops, such as sugarcane. Due to the agricultural practices of soil preparation and harvest, the areas occupied by those crops periodically lose a great portion of their fauna, and are mighty dependent upon close perennial environments for re-colonization. More complex and diversified environments close to mono-cultivation allow increased diversity in the agricultural ecosystems. Due to higher diversity in those areas, mainly of predators, pests will not be able to become dominants and threaten the crops (Gliessman, 2001). According to Demite and Feres (2005, 2008), presence of native vegetation neighboring crops must to be an important factor upon preparation of programs for ecological management of pests. Therefore, reincorporation of diversity into the agricultural ecosystems is a key strategy for sustainable agriculture (Gliessman, 2001; Altieri et al., 2003).

Maintenance of forest fragments neighboring agricultural areas is desirable; however, it is important that such maintenance is linked to management plan of the neighboring crops in order not to impair preservation of fauna at such natural environments. A set of agricultural practices that do not pose negative impact on such environments favors maintenance of wild species of mites and might contribute to increase diversity, both in the natural environments and in the neighboring agricultural environments.

\section{Acknowledgements}

To Drs. Aníbal R. Oliveira (UESC, Ilhéus), Gilberto J. de Moraes (ESALQ-USP, Piracicaba), Gustavo Q. Romero (UNICAMP, Campinas), Marineide R. Vieira (UNESP, Ilha Solteira) and Rodrigo D. Daud (UFG, Goiânia), for the valuable comments and suggestions to the manuscript. To TT-3/FAPESP scholarship students, Adriano L. Mendonça and Raquel G. Kishimoto (UNESP, São José do Rio Preto) for assistance in mounting the mites. This project has been financed by "Fundação de Amparo a Pesquisa do Estado de São Paulo" within the programs BIOTA/FAPESP Program (FAPESP: Process. No. 04/04820-3 and 06/55725-6) and Jovem Pesquisador (FAPESP: Proc. No. 06/57868-9). The second and third authors are scholarship academics of Productivity in the Research with the "Conselho Nacional de Desenvolvimento Científico e Tecnológico" (CNPq: Proc. no. 303049/2010-3 and 303463/2010-4, respectively).

\section{References}

ALBUQUERQUE, FA., 2006. Diversidade de ácaros em cultivo orgânico de citros e na vegetação natural circundante, $e$ perspectivas para a criação massal de Iphiseiodes zuluagai (Acari, Phytoseiidae). Jaboticabal: UNESP. 108 p. Tese de Doutorado em Agronomia (Entomologia Agrícola).

ALTIERI, MA. and TODD, JW., 1981. Some influencies of vegetational diversity on insect communities of Georgia soybean fields. Protection Ecology, vol. 3, p. 333-338.

ALTIERI, MA., SILVA, NE. and NICHOLLS, CI., 2003. $O$ papel da biodiversidade no manejo de pragas. Ribeirão Preto: Editora Holos. 226 p.

ALVES, EV., CASARIN, NFB. and OMOTO, C., 2005. Mecanismos de dispersão de Brevipalpus phoenicis (Geijskes) (Acari: Tenuipalpidae) em pomares de citros. Neotropical Entomology, vol. 34, no. 1, p. 89-96. http://dx.doi.org/10.1590/ S1519-566X2005000100013.

BERGH, JC. and MCCOY, CW., 1997. Aerial dispersal of citrus rust mite (Acari: Eriophyidae) from Florida citrus grove. Environmental Entomology, vol. 26, no. 2, p. 256-264. http:// dx.doi.org/10.1093/ee/26.2.256.

BERGH, JC., 2001. Ecology and aerobiology of dispersing citrus rust mites (Acari: Eriophyidae) in Central Florida. Environmental Entomology, vol. 30, no. 2, p. 318-326. http:// dx.doi.org/10.1603/0046-225X-30.2.318.

BERNSTEIN, C., 1983. Some aspects of Phytoseiulus persimilis (Acarina: Phytoseiidae) dispersal behavior. Entomophaga, vol. 28, no. 2, p. 185-198. http://dx.doi.org/10.1007/BF02372143.

BERTON, LHC., 2009. Dinâmica populacional de ácaros em cafezal próximo a fragmento florestal e conduzido sob a ação de agrotóxicos no município de Monte Alegre do Sul-SP. São Paulo: Instituto Biológico. 118 p. Dissertação de Mestrado em Sanidade Vegetal, Segurança Alimentar e o Ambiente.

BURGESS, RL. and SHARPE, DM., 1981. Forest island dynamics in man-dominated landascapes. New York: Springer-Verlag. 310 p.

CHIVERTON, PA. and SOTHERTON, NW., 1991. The effects on beneficial arthropods of the exclusion of herbicides from cereal crops edges. Journal of Applied Ecology, vol. 28, no. 3, p. 1027-1039. http://dx.doi.org/10.2307/2404223.

COLLI, GR., ACCACIO, GM., ANTONINI, Y., CONSTANTINO, R., FRANCESCHINELLI, EV., LAPS, RR., SCARIOT, A., VIEIRA, MV. and WIEDERHECKER, HC., 2003. A fragmentação dos ecossistemas e a biodiversidade brasileira: uma síntese. In RAMBAOLDI, DM. and OLIVEIRA, DAS. (Eds.). Fragmentação de ecossistemas: causas, efeitos sobre a biodiversidade $e$ recomendações de políticas públicas. Brasília: Ministério do Meio Ambiente/Secretaria de Biodiversidade e Florestas. p. 317-324.

COOMBES, DS. and SOTHERTON, NW., 1986. The dispersal and distribuition of polyphagous predatory Coleoptera in cereals. Annals of Applied Biology, vol. 108, no. 3, p. 461-474. http:// dx.doi.org/10.1111/j.1744-7348.1986.tb01985.x.

DEMITE, PR. and FERES, RJF., 2005. Influência de vegetação vizinha na distribuição de ácaros (Acari) em seringal no município de São José do Rio Preto, São Paulo, Brasil. Neotropical Entomology, vol. 34, no. 5, p. 829-836. http://dx.doi.org/10.1590/ S1519-566X2005000500016. 
DEMITE, PR. and FERES, RJF., 2007. Influência de fragmentos de cerrado na infecção fúngica em ácaros de seringueira. Arquivos do Instituto Biologico, vol. 74, p. 271-273.

DEMITE, PR. and FERES, RJF., 2008. Influência de fragmentos de cerrado na distribuição de ácaros em seringal. Neotropical Entomology, vol. 37, no. 2, p. 196-204. http://dx.doi.org/10.1590/ S1519-566X2008000200015. PMid:18506301

GLIESSMAN, SR., 2001. Agroecologia. Porto Alegre: Editora Universidade/UFRGS. 653 p.

HOY, MA., 1990. Pesticide resistance in arthropod natural enemies: variability and selection responses. In ROUSH, RT. and TABASHNIK, BE. (Eds). Pest resistance in arthropods. New York: Chapman and Hall. p. 202-236.

JUNG, C. and CROFT, BA., 2001. Aerial dispersal of phytoseiid mites (Acari: Phytoseiidae): estimating falling speed and dispersal distance of adult females. Oikos, vol. 94, no. 1, p. 182-190. http:// dx.doi.org/10.1034/j.1600-0706.2001.11044.x.

LAURANCE, WF. and BIERREGAARD JUNIOR, RO., 1997. Tropical forest remnants: ecology, management, and conservation of fragment communities. Chicago: The University of Chicago Press. $504 \mathrm{p}$

LAURANCE, WF. and YENSEN, E., 1991. Predicting the impacts of edge effects in fragments habitats. Biological Conservation, vol. 55, no. 1, p. 77-92. http://dx.doi.org/10.1016/0006-3207(91)90006-U.

LOFEGO, AC., DEMITE, PR., KISHIMOTO, RG. and MORAES, GJ., 2009. Phytoseiid mites on grasses in Brazil (Acari: Phytoseiidae). Zootaxa, vol. 2240, p. 41-59.

LOFEGO, AC., MORAES, GJ and CASTRO, LAS., 2004. Phytoseiid mites (Acari: Phytoseiidae) on Myrtaceae in the State of São Paulo, Brazil. Zootaxa, vol. 516, p. 1-18.

LOVEJOY, TE., BIERREGAARD JUNIOR, RO., RYLANDS, AB., MALCOLM, JR., QUINTELA, CE., HARPER, LH., BROWN JUNIOR, KS., POWELL, AH., POWELL, GVN., SCHURBART, HOR. and HAYS, MB., 1986. Edge and other effects if isolation on Amazon Forest fragments. In SOULÉ, ME. (Ed). Conservation biology: the science of scarcity and diversity. Sunderland: Sinauer Associates. p. 257-285.

MURCIA, C., 1995. Edge effects in fragmented forests: implications for conservation. Trends in Ecology \& Evolution, vol. 10, no. 2, p. 58-62. http://dx.doi.org/10.1016/S0169-5347(00)88977-6. PMid:21236953

PATTON, DR., 1975. A diversity index for quantifying habitat edge. Wildlife Society Bulletin, vol. 3, p. 171-173.

PERFECTO, I. and VANDERMEER, JA., 2002. Quality of agroecological matrix in a tropical montane landscape: ants in coffee plantations in southern Mexico. Conservation Biology, vol. 16 , no. 1 , p. 174-182. http://dx.doi.org/10.1046/j.15231739.2002.99536.x

SATO, ME., CERÁVOLO, LC., CEZÁRIO, AC., RAGA, A. and MONTS, SMNM., 1994. Toxicidade de acaricidas a Euseius citrifolius Denmark \& Muma, 1970 (Acari: Phytoseiidae) em citros. Revista de Agricultura, vol. 69, p. 257-267.
SATO, ME., CERÁVOLO, LC., ROSSI, AC., RAGA, A. and SOUZA FILHO, MF., 1996. Toxicidade residual de acaricidas a Iphiseiodes zuluagai Denmark \& Muma, 1972 (Acari: Phytoseiidae). Arquivos do Instituto Biologico, vol. 63, p. 15-19.

SAUNDERS, DA., HOBBS, RJ. and MARGULES, CR., 1991. Biological consequences of ecosystem fragmentation: a review. Conservation Biology, vol. 5, no. 1, p. 18-32. http://dx.doi. org/10.1111/j.1523-1739.1991.tb00384.x.

SILVA, EA., REIS, PR., ZACARIAS, MS. and MARAFELI, PP., 2010. Fitoseídeos (Acari: Phytoseiidae) associados a cafezais e fragmentos florestais vizinhos. Ciência e Agrotecnologia, vol. 34, no. 5, p. 1146-1153. http://dx.doi.org/10.1590/S141370542010000500010

TABARELLI, M. and GASCON, C., 2005. Lições da pesquisa sobre fragmentação: aperfeiçoando políticas e diretrizes de manejo para a conservação da biodiversidade. Megadiversidade, vol. 1 , p. $181-188$

TIXIER, MS., KREITER, S. and AUGER, P., 2000. Colonization of vineyards by phytoseiid mites: their dispersal patterns in the plot and their fate. Experimental \& Applied Acarology, vol. 24, no. 3, p. 191-211. http://dx.doi.org/10.1023/A:1006332422638. PMid: 11108386

TIXIER, MS., KREITER, S., AUGER, P. and WEBER, M., 1998. Colonization of Langhedoc vineyards by phytoseiid mites (Acari: Phytoseiidae): influence of wind and crop environment. Experimental \& Applied Acarology, vol. 22, no. 9, p. 523-542. http://dx.doi.org/10.1023/A:1006085723427.

TSCHARNTKE, T., 1992. Fragmentation of Phragmites habitats, minimum viable population size, habitat suitability, and local extinction of moths, midges, flies, aphids and birds. Conservation Biology, vol. 6, no. 4, p. 530-536. http://dx.doi.org/10.1046/j.15231739.1992.06040530.x

TSCHARNTKE, T., STEFFAN-DEWENTER, I., KRUESS, A. and THIES, C., 2002. Contribution of small habitat fragments to conservation of insect communities of grassland-cropland landscapes. Ecological Applications, vol. 12, p. 354-363.

VANDERMEER, JA. and PERFECTO, I., 1997. The agorecosystem: a need for the conservation biologist's lens. Conservation Biology, vol. 11 , no. 3, p. 591-592. http://dx.doi.org/10.1046/j.15231739.1997.07043.x.

VIDAL, C. and KREITER, S., 1995. Resistance to a range of insecticides in the predaceous mite Typhlodromus pyri (Acari: Phytoseiidae): inheritance and physiological mechanisms. Journal of Economic Entomology, vol. 88, no. 5, p. 1097-1105. http:// dx.doi.org/10.1093/jee/88.5.1097.

WILCOVE, DS., MCLELLAN, CH. and DOBSON, AP., 1986. Habitat fragmentation in the temperature zone. In SOULÉ, ME. (Ed.). Conservation biology: the science of scarcity and diversity. Sunderland: Sinauer Associates. p. 237-256.

ZAR, JH., 1999. Biostatistical analysis. New Jersey: PrenticeHall. 718 p. 